\title{
REALISING THE POTENTIAL OF MANUFACTURING EXECUTION SYSTEMS
}

\author{
L van Dyk \& CD van Schoor \\ Department of Industrial and Systems Engineering, \\ School of Engineering \\ University of Pretoria \\ Lvdyk@up.ac.za, Cschoor@up.ac.za
}

\begin{abstract}
The term Manufacturing Execution System (MES) was created by Advanced Manufacturing Research (AMR) in 1990 to describe a suite of software products, which enables the execution of manufacturing through the integration of the planning and control systems of an enterprise. The evolution of Manufacturing Execution Systems is a result of the evolution of manufacturing strategies, manufacturing planning and control systems, as well as the evolution of information technology. In this article this evolution is investigated, current business models are evaluated and an MES Function Matrix is proposed to address inadequacies of these models.
\end{abstract}

\section{OPSOMMING}

Die term Vervaardigingsuitvoeringstelsels ("Manufacturing Execution System" - MES) is in 1990 deur Advanced Manufacturing Research (AMR) geskep om die stel sagtewareprodukte te beskryf, wat die uitvoering van vervaardigingsplanne moontlik maak deur die integrasie van die beplanning- en beheerstelsels van 'n onderneming. Die evolusie van MES is die resultaat van die ontwikkeling van vervaardigingstrategieë, vervaardingsbeplanning- en beheerstelsels, asook die ontwikkeling van inligtingstegnologie. In hierdie artikel word die evolusie van MES ondersoek, besigheidsmodelle word geëvalueer en 'n MES Funksie Matriks word voorgestel om leemtes ten opsigte van hierdie modelle te identifiseer. 


\section{INTRODUCTION}

The term Manufacturing Execution System (MES) was created by Advanced Manufacturing Research (AMR) in $1990^{1}$. The term is used to describe the suite of software products, which enables the execution of manufacturing through the integration of the planning and control systems of an enterprise [1]. Communication between the execution and control systems occurs normally in real time. This is not the case as far as the interface between the execution and planning systems is concerned.

Since 1990 the use of the term MES became more and more popular and it is now accepted within many industries. However, due to the scope of the above definition, the term MES are not used consistently. Many manufacturers and software developers realise that an MES is not something new or something only needed by large, complex manufacturers. If you have a manufacturing plant, you already have an MES [2]. For this reason, current systems, products and needs are often categorised as MES without considering the broader picture. The opportunity to benefit from MES capabilities is often missed when current systems are simply treated as MES, without considering the scope and potential benefits of an MES for that specific business/industry.

MES benefits include the coordination of support functions, management of the shop floor, as well as the execution and communication of work status and problems. Through an integrated MES, work orders and current shop floor activities can be traced to provide immediate knowledge of changes from the proposed schedule. "An execution-driven approach can complement existing systems such as MRP, but manufacturers gain real-time visibility constraints in the manufacturing process." [3] An MES enables the identification of potential problems or bottlenecks before they occur, and coordinate shop floor and support department activities so that work assignments can be executed within a synchronized operating unit.

These benefits are not the only reason why companies should consider the utilisation of their MES. Many MES benefits are industry and company-specific and are not listed above. In this article, the concept of MES is introduced and models are evaluated to enable the current and potential users of MES to consider the scope, application and benefits thereof within each individual businesses and industries.

\footnotetext{
${ }^{1}$ AMR Research is an industry and market analysis firm specialising in enterprise applications and related trends and technologies. Tracking more than 400 leading software and service providers, AMR Research helps Global 1000 companies evaluate, select, and manage new systems for every part of the enterprise, including logistics and supply-chain management, Enterprise Resource Planning (ERP), Manufacturing Execution Systems (MES), and electronic commerce.

(www.amresearch.com)
} 


\section{THE EVOLUTION OF MES}

"As the information technology revolution was taking place, MES grew up out of automated data collection systems, and like the evolution of MRP into MRPII, functionality was added bit by bit, until a functional critical mass established a clear point of differentiation." [4]

In Figure 1 (on the following page) the evolution of MES is shown. Factors, which influenced the evolution of MES, can be categorised as follow:

- Manufacturing Strategy

- Manufacturing Planning and Control Systems

- Information Technology

Trends within these categories are indicated on the same time scale in Figure 1. The evolution of MES is discussed according to changes in each of these categories.

\subsection{The Evolution of Manufacturing Strategy}

Table 1 is an extract from evolving management perspectives by Chase and Aquilano [5]. MES can be positioned as an information technology based solution to accomplish business integration, agile manufacturing and flexibility.

Table 1: Evolving Management Perspectives

\begin{tabular}{|l|l|l|l|l|l|}
\hline \multicolumn{1}{|c|}{ Time Line } & $1920-1980 \mathrm{~s}$ & $1980-1990$ & $1990-1995$ & $1995-2000$ & \multicolumn{1}{|c|}{$\begin{array}{c}\text { 2000 and } \\
\text { beyond }\end{array}$} \\
\hline $\begin{array}{l}\text { Manufacturing } \\
\text { epoch }\end{array}$ & $\begin{array}{l}\text { Mass } \\
\text { production }\end{array}$ & $\begin{array}{l}\text { Lean } \\
\text { production }\end{array}$ & $\begin{array}{l}\text { Agile } \\
\text { manufacturing }\end{array}$ & $\begin{array}{l}\text { Agile } \\
\text { manufacturing }\end{array}$ & $\begin{array}{l}\text { Strategic } \\
\text { agility }\end{array}$ \\
\hline $\begin{array}{l}\text { Competitive } \\
\text { priorities }\end{array}$ & Cost & Quality & Delivery & Flexibility & $\begin{array}{l}\text { Knowledge } \\
\text { factory }\end{array}$ \\
\hline Process criteria & $\begin{array}{l}\text { Scale } \\
\text { efficiencies }\end{array}$ & $\begin{array}{l}\text { Continuous } \\
\text { improvement }\end{array}$ & $\begin{array}{l}\text { Time/quick } \\
\text { response }\end{array}$ & $\begin{array}{l}\text { Economies of } \\
\text { scope/ } \\
\text { integration }\end{array}$ & $\begin{array}{l}\text { Mass } \\
\text { personalisation } \\
\text { Economies of } \\
\text { knowledge }\end{array}$ \\
\hline $\begin{array}{l}\text { Source of value } \\
\text { added }\end{array}$ & $\begin{array}{l}\text { Capital/ } \\
\text { muscle } \\
\text { power }\end{array}$ & $\begin{array}{l}\text { Local } \\
\text { information } \\
\text { systems / } \\
\text { work teams }\end{array}$ & $\begin{array}{l}\text { Supply chain } \\
\text { systems/cross } \\
\text { functional } \\
\text { teams }\end{array}$ & $\begin{array}{l}\text { IT enabled } \\
\text { processes/ } \\
\text { Process } \\
\text { expertise and } \\
\text { relationships }\end{array}$ & $\begin{array}{l}\text { Intelligent } \\
\text { systems } \\
\text { Communities } \\
\text { of practice }\end{array}$ \\
\hline
\end{tabular}




\begin{tabular}{|c|c|c|}
\hline $\begin{array}{c}\text { MANUFACTURING } \\
\text { STRATEGY }\end{array}$ & $\begin{array}{l}\text { MANUFACTURING } \\
\text { PLANNING AND } \\
\text { CONTROL SYSTEMS }\end{array}$ & $\begin{array}{l}\text { INFORMATION } \\
\text { TECHNOLOGY }\end{array}$ \\
\hline $\begin{array}{r}1970 \\
\text { Economies of scale } \\
\text { Mass production }\end{array}$ & $\begin{array}{l}\text { The first computerised business } \\
\text { systems } \\
\text { Material Requirements Planning } \\
\text { (MRP) } \\
\text { Distribution Resource Planning } \\
\text { (DRP) }\end{array}$ & $\begin{array}{l}1970 \\
\text { Current PLC paradigm is } \\
\text { developed }\end{array}$ \\
\hline $\begin{array}{r}1980 \\
\text { Quality } \\
\text { Continuous Improvement }\end{array}$ & $\begin{array}{l}\text { Manufacturing Resource Planning } \\
\text { (MRPII) } \\
\text { Closed-loop MRP } \\
\text { Manufacturing Execution Systems } \\
\text { (MES) used under different } \\
\text { names, e. g. Computer Integrated } \\
\text { Manufacturing } \\
\text { Supply Chain Management (SCM) } \\
\text { Enterprise Resource Planning } \\
\text { (ERP) }\end{array}$ & $\begin{array}{l}1980 \\
\text { Relational databases } \\
\text { Computing hardware } \\
\text { Operating systems }\end{array}$ \\
\hline $\begin{array}{r}1990 \\
\text { Delivery } \\
\text { Global competition intensified } \\
\text { Upgrade manufacturing } \\
\text { capability } \\
\text { Productivity Improvement } \\
\text { Waste reduction } \\
\text { Greater product variety } \\
\text { Just-in l-time (JIT) philosophies } \\
\text { Supply chain systems } \\
\text { Economies of scope/integration }\end{array}$ & $\begin{array}{c}\text { The term MES is created } \\
\text { Integrated MES } \\
\text { Business Process Reengineering } \\
\text { (BPR) } \\
\text { Supply Chain Management } \\
\text { REPAC Model }\end{array}$ & $\begin{array}{l}1990 \\
\text { Object orientated programming } \\
\text { Client/server technology } \\
\text { The Internet }\end{array}$ \\
\hline & $\begin{array}{l}\text { The gap between planning and } \\
\text { control systems narrows }\end{array}$ & 00 \\
\hline
\end{tabular}


The evolution of management perspective and strategies (Table 1) is in line with the explanation of Willis [6]: "Economies of scale and mass production were dominant elements of the manufacturing strategies in the 1950s, 1960s and 1970s. To be managed and controlled, facilities had to be large and complex." In the 1980s there was a shift in emphasise from mass production to quality. Customer-driven quality, continuous improvement, quick response, design for quality and prevention and partnership development were promoted as part of the philosophy of Total Quality Management (TQM) [7].

Agile manufacturing became a requirement in the late 1980s and 1990s under the pressure of global competition [3]:

"The emphasis has shifted towards partnerships with customers and suppliers, and highly flexible organisations and processes, which can produce exactly what the customer wants in a fraction of the time at a fraction of the cost of the old methods. Responsive, adaptive organisations are focusing on the processes required to meet specific customer demands."

Manufacturing Execution systems evolved accordingly to enable manufacturers to respond to changes in production processes, priorities and market dynamics and to accomplish manufacturing agility [4].

\subsection{Planning and Control Systems}

Computers were initially used only to automate business processes related to accounting. By the late 1960 s / early 1970s material requirements planning (MRP) evolved from these accounting systems. It was intended to help manufacturers better plan material availability [3].

By the late 1970s / early 1980s, computers became more powerful and capable of handling more data used interactively by more people. MRP evolved into MRPII as shop floor reporting systems, purchasing systems and related functions were added. At about the same time, many companies began to realise they needed other systems to manage other aspects of their businesses. Neither the requirements of forecasting and managing demand in distribution, nor the management of the shop floor is addressed by MRPII.

In the late 1980s and early 1990s, another generation of systems became available [3]. These systems attempted to solve the so called "islands of information problem" by providing broad comprehensive solutions. MRPII systems became Enterprise Resource Planning. DRP became Supply Chain Management and the shop floor solutions evolved into integrated MES systems.

According to Reynolds [8], Manufacturing Resource Planning (MRPII) and Enterprise Resource Planning (ERP) systems developed in an effort to close the production knowledge loop. These solutions offered the promise of having production respond to delivery commitments. However, systems were still needed to provide the detailed tracking and quality information customers are demanding more frequently, or the process information that would enable manufacturers to ensure repeatability of their processes. MES developed accordingly to bridge the gap that was caused by the lack of information from the plant floor that was required to provide the necessary status [9]. 


\subsection{Information Technology}

The Information Technology explosion is the single most important reason for the rapid evolution of MES over the past decade. The Information Technology to support large scale distributed networks becomes more and more user-friendly and cost effective [10]. Installations can take place over time to suit the customer.

The impact of Internet technology is of special interest. Web browsers, internet-enabled applications, viewing tools and home pages contributes towards inexpensive, scalable enterprise-wide integration. Internet browsers and Java applications provide the mechanism whereby a business application can intelligently access and retrieve data across internet/ intranet/ extranet [11]: "The browser works across the horizontal business layer from suppliers to customers. For example, purchasing uses the Internet to search for suppliers of specific products, prices, availability, specifications and delivery dates. With contracted suppliers the internet allow access to the inventory levels of every plant of location that stocks their products worldwide."

\section{MES BUSINESS MODELS}

MES is a fairly new concept (being defined in 1990). It is thus not surprising that MES business models are evolving rapidly. These models are discussed in this section.

\subsection{MES Context Model}

The MES Context Model by MESA International ${ }^{2}[12]$ in Figure 2 illustrates the integration of MES with different business systems in a manufacturing environment.

"MES provides an information hub that links to and sometimes between all of these systems. MES overlaps with other manufacturing system types, which overlap each other. For example, scheduling may appear in both MES and SCM; labor management in MES, SSM and the HR function of ERP; document control in MES and P/PE; and process management in both MES and Controls. Degrees of overlap vary by industry and implementation" [12].

Planning systems usually reacts and reports on changes, which already occurred. They are not designed to be pro-active to anticipate or react to daily plant floor changes.

MRPII systems were essentially designed to integrate all the operational functions of a manufacturing organisation (from engineering through to production) and to change from reactionary management to top-down planning [12]. However, the replacement of the ability to manage reactively did not replace the need to react on changes. Without replacing MRPII systems, Manufacturing Execution Systems are integrated with business systems, to enable the necessary bottom-up reactionary management.

\footnotetext{
${ }^{2}$ MESA International (Manufacturing Execution Systems Association) is a not-for-profit trade association providing a legal forum for competitors to work together to expand awareness and use of manufacturing technology, particularly MES and all the related products and services required by the modem manufacturing enterprise. (www.MESA.org)
} 


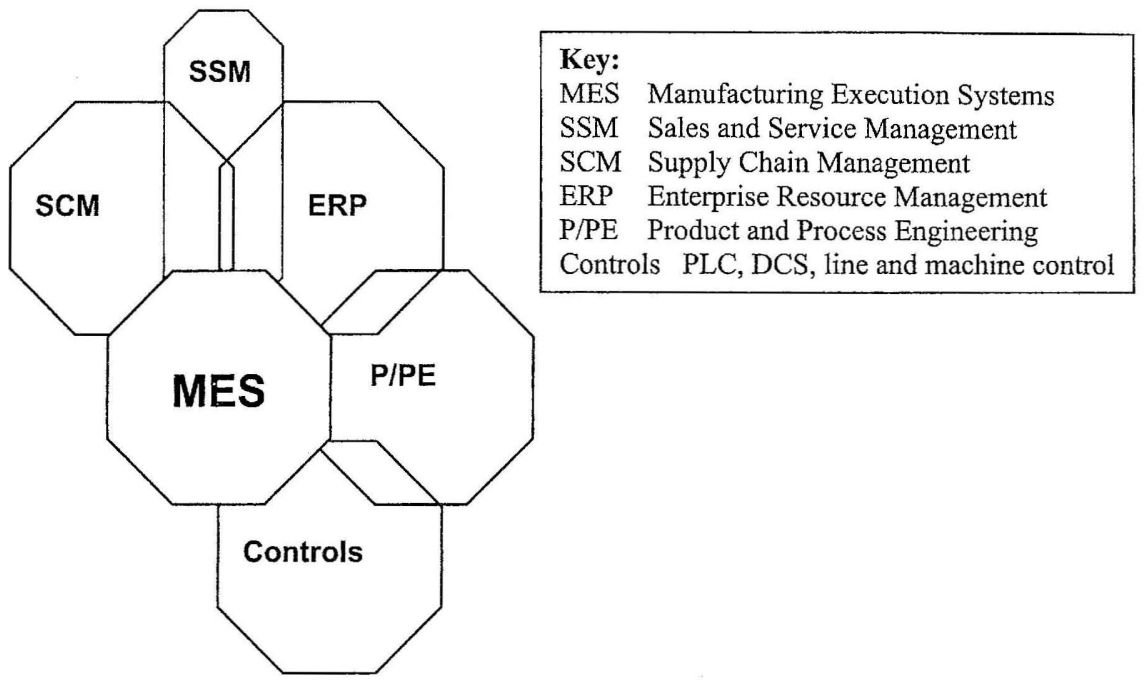

\subsection{MES Three Layer Model}

AMR Research developed a simple model to explain the position of Manufacturing Execution Systems (Figure 3 on the following page). This model - called the Three-Layer model - is now widely accepted by manufacturing industry and appears in the majority of MES literature. According to this model the three main activities within a business are related to three groups of information systems:

- The top layer comprises systems such as Enterprise Resource Planning (ERP), Manufacturing Resource Planning (MRPII), Material Requirements Planning (MRP), Capacity Requirements Planning (CRP) and Supply Chain Management (SCM). Plans are sent down in batch mode to the execution layer. Information on how the plans are executed is received from the execution layer.

- The execution layer acts as link between the control and planning layers. Communication between the execution and control layers occurs in real-time.

- Control is established through devices and systems such as programmable logic controllers (PLC's), Supervisory Control and Data Acquisition (SCADA) and Man Machine Interfaces (MMI's). Information is sent in real-time to the execution layer. The execution layer sends back the appropriate instructions, based on process, maintenance and safety procedures. 
Figure 3: Three-Layer Model by AMR Research

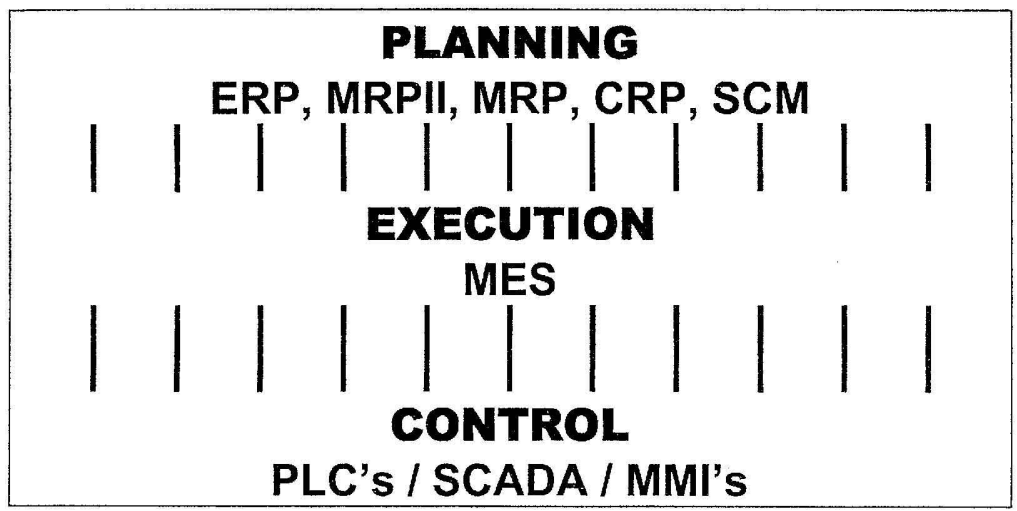

\subsection{MES Data Flow Model}

MESA International expanded on the Three-Layer-Model: The flow of data between the MES layer and its neighbouring layers is shown in Figure 5 (on the next page). Arrows indicate the data flowing to and from each of these layers, while the transformation of data is indicated within the boundaries of each layer.

Complementary to Figure 5, MES is positioned in an enterprise data flow Figure 4, showing the interaction between MES and people and devices that functions within it [13].

Figure 4: MES in an Enterprise Data Flow Diagram

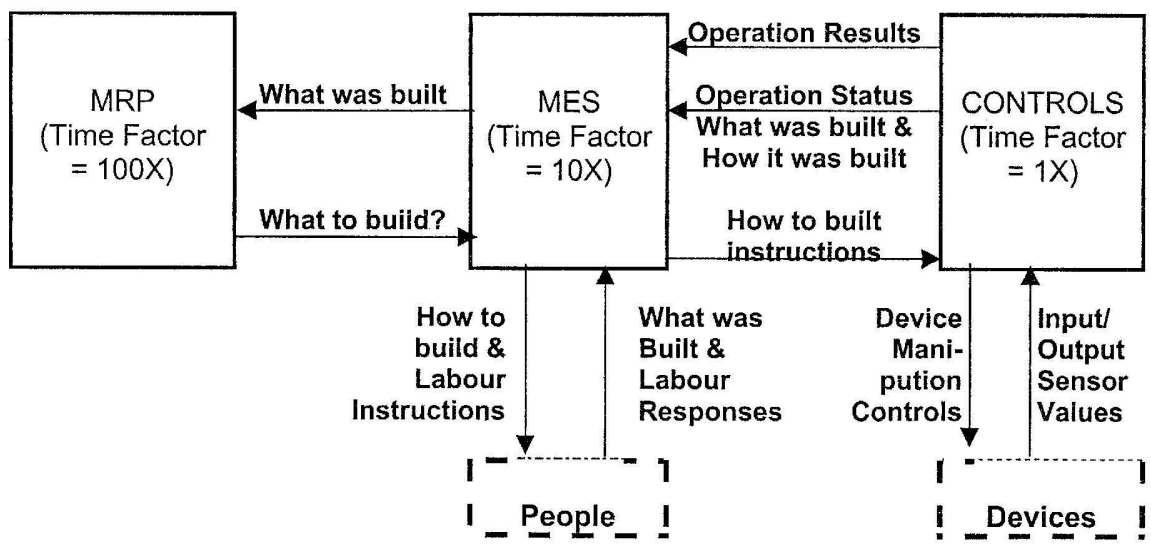


Figure 5: Data Flow Between MES and Planning and Control Systems

PLANNING

\begin{tabular}{|l|}
\hline ERP / MRPII \\
COMMS \\
Engineering \\
Forecasting \\
Costing \\
Production \\
planning \\
Product definition \\
Process definition \\
Human resources \\
Inventory \\
management \\
Purchasing \\
Distribution \\
Docision \\
Location: \\
Office \\
\hline
\end{tabular}

EXECUTION

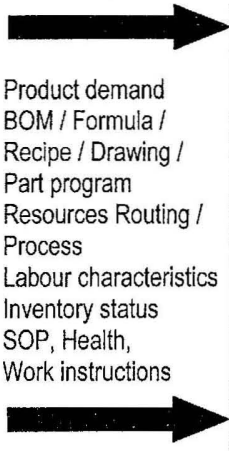

Resource

allocation/ status

Operations

Scheduling

Product

dispatching

Document control

Labour

management

WIP status/

tractability

Quality

management

Performance

Order status / analysis

completions

Start-due-end

Resource

status/usage

Labour status/usage

Product tracking

and genealogy

Maintenance

management

Material status/usage

Actual BOM /

Formula / Recipe /

Drawing / Part

program

Product genealogy /

tractability

As build information

Scrap / waste

CONTROL

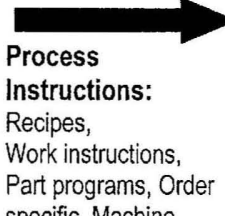

specific, Machine

utilisation,

Work certification,

Requirements

Operator

instructions:

Scheduled

(predictive)

\& preventative

maintenance,

Material safety

instructions (docs),

Machine operation

instructions (docs)

Drill down

(inquiries)

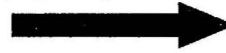

Product Status

Batch End Report

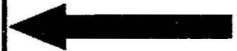

Ad hoc inquiries Materials analysis

Events:

Time/Data/Lot/Alarms

Data collected from monitoring functions Process, equipment, environment, labour, material, product parameters
Monitoring \& Sensing

Process,

Equipment,

Environment, Labour,

Material

\section{Control}

Machine control

Regulatory control

Real time QC

Advanced process

control

\section{Operations}

Process

sequencing

Machine \&

process

instructions

Labour

instructions

Human machine

interfacing

Safety

Maintenance

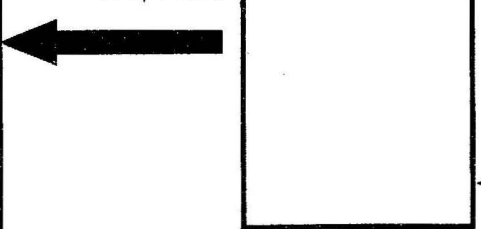

\begin{tabular}{l}
\hline Focus: \\
Product \\
Decision \\
Location: \\
Factory / Plant \\
\hline
\end{tabular}

Focus:

Process

Decision

Location:

Shop / Plant Floor 
"A Control System is defined as being 'responsible for measurement, monitoring, and manipulation of production, people, products, and processes' within the environment of the process or shop floor. " [10]

Controls are usually hybrid hardware/software systems such as distributed control systems, programmable logic controllers, distributed numerical control and supervisory control and data acquisition systems, designed to automate the way in which the product is being manufactured [14].

The focus of control systems is the process or operation itself - sequencing and manipulating the process to assure that:

- tolerances are kept within defined limits,

- material flow is maintained and

- people, equipment, and resources involved within the process are fully utilised.

The control layer concerns inputs and outputs or status points of the process. These points can be:

- relayed as they occur,

- trended as part of the functionality within the controls themselves, or

- stored in databases for analysis,

to assure that the product or process is progressing within defined limits.

Forger [9] explains that data are gathered by controls through technology such as bar codes, radio frequency data communications, and radio frequency identification.

The specific performance of a piece of equipment, or an operator, may not be as important to the execution layer as it would be to a control operator. The results from these discrete operations would be blended into the process control data, and then those results would be communicated to the execution systems.

Drill-down inquiries, or status indicators, from the execution layer can spontaneously access information created on an as-needed basis for process control. There are also bilateral inquiries that can emerge from either layer: these inquiries can be used to measure progressto-plan, to communicate unscheduled changes, or to announce alarms, events or changes that have occurred [15].

(b) Data flow between the MES and Planning Systems

The MES provides the basic interface between planning and execution. The expanded interface has information flowing both ways with factory floor information aiding the office system in job costing, payroll, lot control, and inventory management. 
According to MESA International [15] the planning layer normally does not function in realtime, but rather in a batch mode. The planning layer notes product usage, customer orders and materials requirements, and sends requests to the execution layer to build more product in order to fulfil these needs. The MES is responsible for carrying out the manufacturing of a product - and all operations associated with the creation of those products.

The MES uses information not generally found in office systems. In those cases where planning systems provide some information, the MES defines additional data elements in order to organise manufacturing operations on a realistic basis. Such deviations and improvements by the MES also means that a constant feedback to the planning program is needed so that purchasing is aware of any changes in required materials.

\subsection{MES Function Model}

The MES Function Model in Figure 6 is a combination of the MES Context model (Figure 2) and the Data Flow Model (Figure 5):

Eleven MES Functions - as listed in the execution layer of the Data Flow Model - are positioned on the framework of the MES Context Model to show the interface between MES functions and other systems, as well as the interaction within the layers. A description of these functions, according to MESA International, is given in Table 2 (following page).

\section{Figure 6: The MES Function Model}

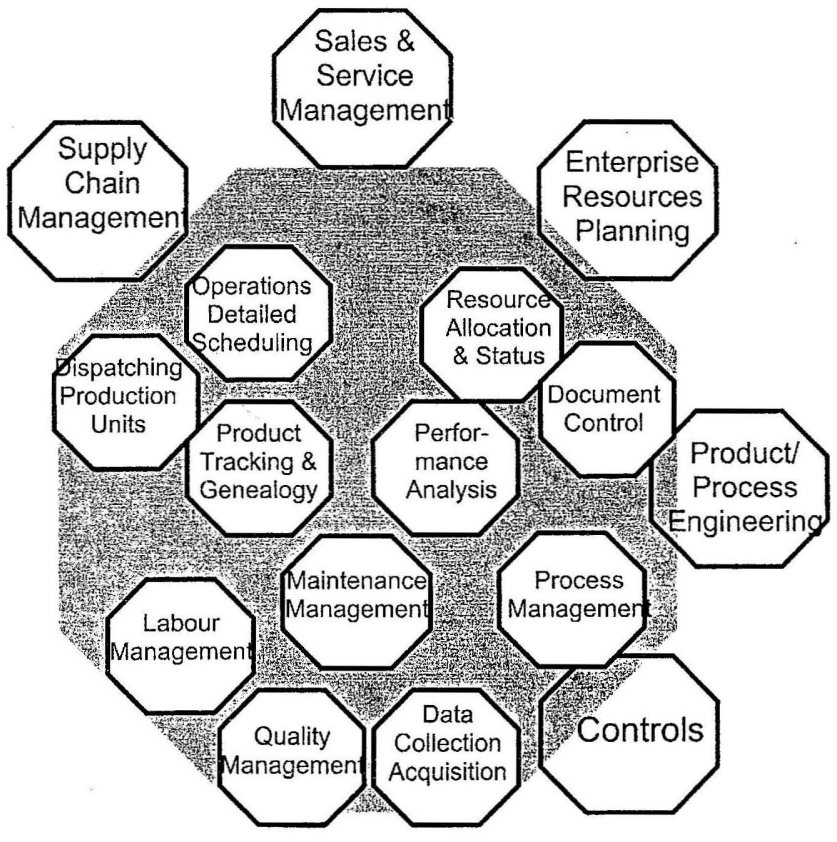


Table 2: MES Functions, according to MESA International [15]

\begin{tabular}{|c|c|}
\hline $\begin{array}{l}\text { Resource } \\
\text { Allocation } \\
\text { and Status }\end{array}$ & $\begin{array}{l}\text { Manages resources including machines, tools labour skills, materials, other } \\
\text { equipment, and other entities such as documents that must be available in order } \\
\text { for work to start at the operation. It provides detailed history of resources and } \\
\text { insures that equipment is properly set up for processing and provides status real } \\
\text { time. }\end{array}$ \\
\hline $\begin{array}{l}\text { Operations } \\
\text { / Detail } \\
\text { Scheduling }\end{array}$ & $\begin{array}{l}\text { Provides sequencing based on priorities, attributes, characteristics, and / or } \\
\text { recipes associated with specific production units at an operation such as shape } \\
\text { of colour sequencing or other characteristics which, when scheduled in } \\
\text { sequence properly, minimize set - up. }\end{array}$ \\
\hline $\begin{array}{l}\text { Dis- } \\
\text { patching } \\
\text { Production } \\
\text { Units }\end{array}$ & $\begin{array}{l}\text { Manages flow of production units in the form of jobs, orders, batches, lots, and } \\
\text { work orders. Dispatch information is presented in sequence in which the work } \\
\text { needs to be done and changes in real time as events occur on the factory floor. } \\
\text { It has the ability to alter prescribed schedule on the factory floor. }\end{array}$ \\
\hline $\begin{array}{l}\text { nent } \\
\text { ol }\end{array}$ & $\begin{array}{l}\text { Controls records / forms that must be maintained with the production unit, } \\
\text { including work instructions, recipes, drawings, standard operation procedures, } \\
\text { part programs, batch records, engineering change notices, shift - to - shift } \\
\text { communication, as well as the ability to edit operations, including providing data } \\
\text { to operators or recipes to device controls. It would also include the control and } \\
\text { integrity of environmental, health and safety regulations, and ISO information } \\
\text { such as Corrective Action procedures. }\end{array}$ \\
\hline $\begin{array}{l}\text { Data } \\
\text { Collection / } \\
\text { Acquisition }\end{array}$ & $\begin{array}{l}\text { This function provides an interface link to obtain the intra - operational } \\
\text { production and parametric data, which populate the forms and records which } \\
\text { were attached to the production unit. }\end{array}$ \\
\hline $\begin{array}{l}\text { Labour } \\
\text { Manage- } \\
\text { ment }\end{array}$ & $\begin{array}{l}\text { Provides status of personnel in and up - to - the - minute time frame. Includes } \\
\text { time and attendance reporting, certification tracking, as will as the ability to track } \\
\text { indirect activities such as material preparation or tool room work as a basis for } \\
\text { activity based costing. It may interact with resource allocation to determine } \\
\text { optimal assignments. }\end{array}$ \\
\hline $\begin{array}{l}\text { Quality } \\
\text { Manage- } \\
\text { ment }\end{array}$ & $\begin{array}{l}\text { Provides real time analysis of measurements collected from manufacturing to } \\
\text { assure proper product quality control and to identify problems requiring } \\
\text { attention. It may recommend action to correct the problem, including correlation } \\
\text { the symptom, actions and results to determine the cause. }\end{array}$ \\
\hline $\begin{array}{l}\text { Process } \\
\text { Manage- } \\
\text { ment }\end{array}$ & $\begin{array}{l}\text { Monitors production and either automatically corrects or provides decision } \\
\text { support to operators for correcting and improving in - process activities. These } \\
\text { activities may be intra - operational and focus specifically on machines or } \\
\text { equipment being monitored and controlled as well as inter - operational, which is } \\
\text { tracking the process from on operation to the next. }\end{array}$ \\
\hline $\begin{array}{l}\text { Mainte- } \\
\text { nance } \\
\text { Manage- } \\
\text { ment }\end{array}$ & $\begin{array}{l}\text { Tracks and directs the activities to maintain the equipment and tools to insure } \\
\text { their availability for manufacturing and insure scheduling for periodic or pre- } \\
\text { ventive maintenance as well as the response (alarms) to immediate problems. It } \\
\text { maintains a history of past events or problems to aide in diagnosing problems. }\end{array}$ \\
\hline $\begin{array}{l}\text { Product } \\
\text { Tracking } \\
\text { and } \\
\text { Genealogy }\end{array}$ & $\begin{array}{l}\text { Provides the visibility to where work is at all times and its disposition. Status } \\
\text { information may include who is working on it; components materials by supplier, } \\
\text { lot, serial number, current production conditions, and any alarms, rework, or } \\
\text { other exceptions related to the product. The on line tracking function creates a } \\
\text { historical record, as well. }\end{array}$ \\
\hline $\begin{array}{l}\text { Perfor- } \\
\text { mance } \\
\text { Analysis }\end{array}$ & $\begin{array}{l}\text { Provides up - to - the - minute reporting of actual manufacturing operations } \\
\text { results along with the comparison to past history and expected business result. } \\
\text { Performance results include such measurements as resource utilization, } \\
\text { resource availability, product unit cycle time, conformance to schedule and } \\
\text { performance to standards. }\end{array}$ \\
\hline
\end{tabular}




\subsection{The REPAC Model}

AMR Research developed the REPAC model, as depicted in Figure 7 below, by the end of 1998. The term REPAC is a concatenation of the first letter of each business process within the scope of this model (ready, execute, process, analyse and coordinate) [16] [17]. The previous models showed the position of MES within a business as well as the interaction between MES and other business layers. The REPAC model expands upon the interaction between MES and other business-enterprise processes.

\section{Figure 7: The REPAC Model}

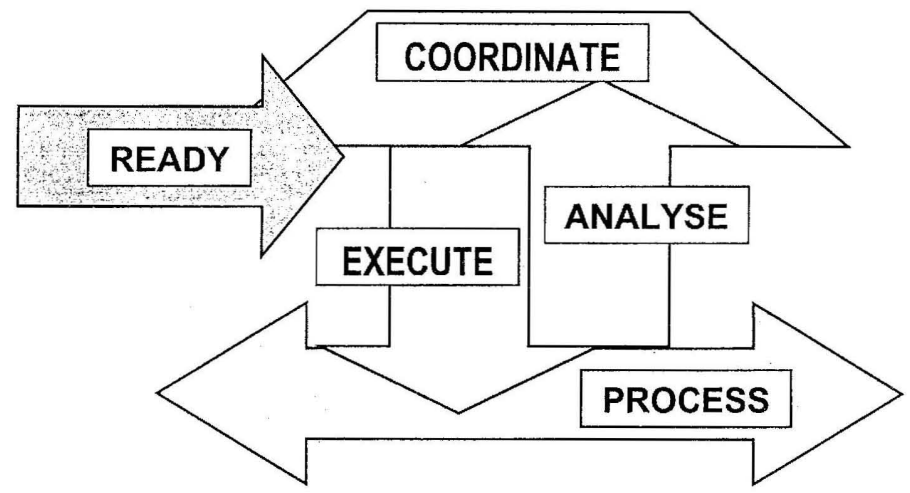

Each of the five business processes within the REPAC model are explained below:

(a) READY new products for production

Through well-controlled production processes, an automated paperless process of new product introduction and engineering change and integrated quality management, life cycles can be reduced, since products can be made ready for production, rapidly [16].

\section{(b) EXECUTE orders for products}

This process is similar to the process occurring on the middle layer of the Context Model (Figure 2) and entails the execution of orders and processes. Similar to classic MES and WIP tracking, the execution of a schedule within the plant is managed, directing plant personnel, equipment, and recording actual progress [16].

\section{(c) PROCESS capability control and management}

The focus of this process is the automation and control of plant systems. Process equipment is often expensive and complex, with sophisticated controls and extensive data collection [16]. 
The process entails the identification and use of key performance information to further improve the process in a number of areas, such as quality and production improvement, calculating key performance indicators, summarizing data for supply chain planners, and assembling product information for downstream use [16].

\section{(e) COORDINATE the plant internally and with the supply chain}

Since the plant is no longer isolated by inventory from the supply chain, a mechanism is necessary to coordinate its operations. This process optimises all of the activities in the plant, using status information from the execute business process and performance information from analyse business process [16].

\section{DEVELOPING A NEW BUSINESS MODEL: THE MES FUNCTION MATRIX}

The models discussed, outlined the positioning of an MES within an enterprise. The eleven functions on the function model (Figure 6) elaborate on the functions of MES by means of specific examples. However, not all businesses are structured in the same way. Some capabilities of MES may be ignored if only the examples within the context model are used as guideline. The need for a generic model that can be used as evaluation and decision making framework is addressed through the development of the MES Function Matrix. Through this matrix it can be determined:

- "What is the MES currently doing?" and

- "What could the MES be doing"?

Value Management/ Analysis [18] suggests that, in order to answer the question "What is a product/ process/ system doing?" the function have to be expressed as a phrase, comprising of a verb, followed by a noun. Accordingly, the function of MES can be described as: EXECUTE MANUFACTURING.

Elements of manufacturing are listed on the y-axis of this matrix, while the elements of execution [19] are listed on the $\mathrm{x}$-axis. The result is 16 sub-functions (in terms of a verb and noun) as indicated in Figure 8 (on the following page). 
Figure 8: MES Function Model

\begin{tabular}{|c|c|c|c|c|c|}
\hline \multicolumn{6}{|c|}{ EXECUTION } \\
\hline \multirow{5}{*}{ 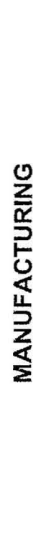 } & & $\begin{array}{l}\text { Guidel } \\
\text { Coordinate }\end{array}$ & Initiate/ Ready & Analyze & React to \\
\hline & $\begin{array}{l}\text { Material/ Parts/ } \\
\text { Product }\end{array}$ & $\begin{array}{l}\text { Guide/ } \\
\text { Coordinate } \\
\text { Materials/ Parts/ } \\
\text { Products }\end{array}$ & $\begin{array}{l}\text { Initiate/Ready } \\
\text { Materials/ Parts/ } \\
\text { Products }\end{array}$ & $\begin{array}{l}\text { Analyze } \\
\text { Materials/ Parts/ } \\
\text { Products }\end{array}$ & $\begin{array}{l}\text { React to } \\
\text { Materials/Parts/ } \\
\text { Products }\end{array}$ \\
\hline & $\begin{array}{l}\text { Labourl } \\
\text { Personnel }\end{array}$ & $\begin{array}{l}\text { Guide/ } \\
\text { Coordinate } \\
\text { Labour/ Personnel }\end{array}$ & $\begin{array}{l}\text { Initiate/ Ready } \\
\text { Labour/ Personnel }\end{array}$ & $\begin{array}{l}\text { Analyze } \\
\text { Labour/Personnel }\end{array}$ & $\begin{array}{l}\text { React to } \\
\text { Labour/Personnel }\end{array}$ \\
\hline & $\begin{array}{l}\text { Equipment/ } \\
\text { Tools/ Fixtures }\end{array}$ & $\begin{array}{l}\text { Guide/ } \\
\text { Coordinate } \\
\text { Equipment/ } \\
\text { Tools/ Fixtures }\end{array}$ & $\begin{array}{l}\text { Initiate/Ready } \\
\text { Equipment/ } \\
\text { Tools/ Fixtures }\end{array}$ & $\begin{array}{l}\text { Analyze } \\
\text { Equipment/ } \\
\text { Tools/ Fixtures }\end{array}$ & $\begin{array}{l}\text { React to } \\
\text { Equipment/ } \\
\text { Tools/ Fixtures }\end{array}$ \\
\hline & $\begin{array}{l}\text { Work } \\
\text { Instructions/ } \\
\text { Specifications/ } \\
\text { Procedures }\end{array}$ & $\begin{array}{l}\text { Guide/ } \\
\text { Coordinate } \\
\text { Work } \\
\text { Instructions/ } \\
\text { Specifications/ } \\
\text { Procedures }\end{array}$ & $\begin{array}{l}\text { Initiate/Ready } \\
\text { Work } \\
\text { Instructions/ } \\
\text { Specifications/ } \\
\text { Procedures }\end{array}$ & $\begin{array}{l}\text { Analyze } \\
\text { Work } \\
\text { Instructions/ } \\
\text { Specifications/ } \\
\text { Procedures }\end{array}$ & $\begin{array}{l}\text { React to } \\
\text { Work } \\
\text { Instructions/ } \\
\text { Specifications/ } \\
\text { Procedures }\end{array}$ \\
\hline
\end{tabular}

The MES Function Matrix can be used to compare MES software products with each other and to evaluate an MES, consisting of more than one software product. Furthermore, it can be used as a guideline to analyse industry specific MES functions.

\subsection{Evaluation of MES software products}

An MES rarely consists of one single software product, that perform all functions. Some MES functions are often performed by systems from the planning layer (e.g. ERP modules) or control layers (e.g. SCADA systems). If the products responsible for each of the functions, suggested by the matrix, are indicated on the matrix, the following can be identified:
$\Rightarrow$ Duplication of the execution of functions.
$\Rightarrow$ Lack of specific functionality
$\Rightarrow$ Lack of integration between functions.

\subsection{Analysis of industry specific MES functions}

McClellan [20] explains that MES are implemented in all manufacturing environments (from discrete manufacturing to process manufacturing). In Table 3 (on the following page) some characteristics of discrete manufacturing and process manufacturing are compared with each other. In the first column the element of manufacturing or execution that is affected by this difference, is listed. The details within the function matrix can be adapted accordingly for each industry. 
Table 3: Discrete manufacturing vs. Process Manufacturing

\begin{tabular}{|l|l|l|}
\hline $\begin{array}{l}\text { Element of } \\
\text { manufacturing/ } \\
\text { execution }\end{array}$ & Discrete manufacturing & Process Manufacturing \\
\hline Material & $\begin{array}{l}\text { Stored and distributed per quantity in } \\
\text { containers }\end{array}$ & $\begin{array}{l}\text { Stored and distributed per volume in } \\
\text { tanks/ silo's/ bulk. }\end{array}$ \\
\hline $\begin{array}{l}\text { Material/ Work } \\
\text { order specification }\end{array}$ & $\begin{array}{l}\text { Value is added through machining, } \\
\text { fabrication and assembling of parts. } \\
\text { Manufacturing and assembling can } \\
\text { be modelled through a bill of material } \\
\text { (BOM) and linked to a discrete } \\
\text { MRPll software package. }\end{array}$ & $\begin{array}{l}\text { Value is added through energy, } \\
\text { equipment and other resources to } \\
\text { blend, separate ingredients and to } \\
\text { cause chemical reactions. }\end{array}$ \\
\hline $\begin{array}{l}\text { Work order } \\
\text { specification }\end{array}$ & $\begin{array}{l}\text { According to bill of material (BOM) } \\
\text { Categorised by item number }\end{array}$ & $\begin{array}{l}\text { According to formula } \\
\text { Categorised by product number }\end{array}$ \\
\hline Equipment & $\begin{array}{l}\text { Capacity can be contracted in/out } \\
\text { easily. }\end{array}$ & $\begin{array}{l}\text { Generally planning have to occur within } \\
\text { the constraints of fixed capacity. }\end{array}$ \\
\hline Analyse & $\begin{array}{l}\text { Easy an accurate to measure (count) } \\
\text { Consistent and predictable quality }\end{array}$ & $\begin{array}{l}\text { Less predictable and time variant } \\
\text { quality. }\end{array}$ \\
\hline
\end{tabular}

\section{FUTURE REQUIREMENTS FOR MES}

The term MES was created to describe the manufacturing systems that enable the execution of manufacturing. Some of these systems already existed, before the term was created. Since the term was created, Manufacturing Execution Systems, as well as its position in the business, evolved rapidly. New models and theories aiming to explain and improve the functionality, business processes and integration of MES, will be developed and the MES market, vendors and integrators will evolve. The way in which manufacturing (and service operations) is planned and controlled will also change.

The need for systems to execute manufacturing plans, however, will not change. In fact, the world of MES is quite young and the application of true computer science to manufacturing questions is barely of the ground. As more suppliers of systems to this market apply computer science to the real opportunities on the plant floor, the economic impact is likely to cause a snowball effect that will dramatically change how plants are managed. Current developments such as client/server technology, object-oriented software programming and data warehousing will facilitate easy integration of systems and flow of information between systems, supporting the idea of "plug and play". Such developments will accelerate the development of MES systems for an increasing number of functions and industry applications.

When considering MES functionality, it is important to realise that the functionality is dispersed across distinct, albeit converging and blurring markets - the MMI/SCADA market and the MES market [14]. Major suppliers of control system solutions increasingly atternpt to provide total industry solutions that may include control hardware and software, advanced control applications, material handling equipment, and production management software. These control companies are looking to enter this arena because of the potential market value of this adjoining industry. Market value is migrating away from hardware-based to softwarebased solutions. This is being driven by a decreasing proportion of manufacturer's capital 
budget spent on industrial equipment versus an increasing proportion spent on information technology.

Developers of planning systems, on the other hand, are continuously adding MES functionality to their products. It can thus be anticipated that the market served by vendors and integrators exclusively focussing on MES are narrowing. The market for MES products as such should, however, maintain the current high rate of growth.

\section{REFERENCES}

[1] AMR Research, Homepage, World Wide Web, http://www.amrresearch.com.

[2] MacDonald, A., Quantifying the Return on Investment, http://www.consilium.com/ Publications/roi.htm, World Wide Web, 1998.

[3] MESA International, Execution-Driven Manufacturing Management for a Competitive Advantage, White Paper Number 5, http://www.MESA.org $/ \mathrm{html} / \mathrm{main} . \mathrm{cgi}$ ? sub=32, World Wide Web, 1996.

[4] Valstar, Manufacturing Execution Systems (MES) Overview, http://www.valstar.co.uk/mes/index. htm, World Wide Web, 1998.

[5] Chase, R.B., Aquilano, N.J. \& Jacobs F.R., Production and Operations Management Manufacturing and Services, eighth edition, McGraw-Hill, United States of America, 1998.

[6] Willis, T.H., "Operational Competitive Requirements for the Twenty-first Century", Industrial Management \& Data Systems, Volume 98, No 2, 83-86, 1998, p.2.

[7] Slack, N., Chambers, S., Harland, C., Harrison, A., Johnston, R., Operations Management, Great Britain, Pearson Education Limited, 1998, p.763.

[8] Reynolds, S., "Camstar: MESAN MES software", Textile World, Vol. 148, No. 4, April 1998, p.81-83.

[9] Forger, G., Take control of your shop floor with Manufacturing Execution Systems, http://www.manufacturing.net/magazine/mmh, World Wide Web, 1997.

[10] CimX, Manufacturing Data Management (MDM), http://www.cimx.com, World Wide Web, 1998.

[11] Clouther, S., "Bridging the Gap: Manufacturing Execution Systems (MES) and Enterprise Resource Planning (ERP), http://www.consilium.com/publications/gap.htm. World Wide Web, 1999.

[12] MESA International, MES Context Model, http://www.MESA.org/html/main.cgi?sub=63, World Wide Web, 1994. 
[13] MESA International, The Controls Layer: Controls Definition and MES to Controls Data Flow Possibilities (White Paper 3), http://www.MESA.org/html/main.cgi?sub=26, World Wide Web, 1995.

[14] Object Management Group, Homepage, http://www.omg.org, World Wide Web, 1998.

[15] MESA International, MES Functions \& MRP to MES Data Flow Possibilities (White Paper 2), http://www.MESA.org/html/main.cgi?sub=25, World Wide Web, 1998.

[16] Heaton, J., Next Generation Plant Systems: The Key to Competitive Plant Operation, AMR Consulting, 1998.

[17] Swanton, B., Do We Need as New Model for Plant Systems?, http://www.amrresearch.com/repac, World Wide Web, October 1998.

[18] Kelly, J. and Male, S., Value Management in design and contruction, 91, E \& FN Spon, an imprint of Chapman \& Hall, 1993, p.91.

[19] Schaeffer, J., "Integrating CMMS with shop floor systems", Plant Services on the Web, http://www.arcweb.com/arcsite/Search/search.asp, World Wide Web, July 1998.

[20] McClellan, M., Applying Manufacturing Execution Systems, St. Lucie Press, Apics Series on Resource Management, 1997, p. 22.

[21] McClellan, M., Applying Manufacturing Execution Systems, St. Lucie Press, Apics Series on Resource Management, 1997, p. 12. 